\title{
Hiện trạng và khả năng dễ bị tổn thương do nhiễm mặn trong bối cảnh biến đổi khí hậu ở thành phố Đà Nẵng
}

\author{
Nguyễn Ngọc Trực ${ }^{1, *}$, Trương Văn Thịnh ${ }^{2}$, \\ Nguyễn Văn Thương ${ }^{1}$, Nguyễn Thảo Ly ${ }^{1}$ \\ ${ }^{1}$ Truòng Đại học Khoa học Tự nhiên, ĐHQGHN, 334 Nguyễn Trãi, Hà Nội, Việt Nam \\ ${ }^{2}$ Trung tâm Phát triển Đại học Quốc gia Hà Nội tại Hòa Lạc, \\ Thạch Hòa, Thạch Thẩt, Hà Nội, Việt Nam \\ Nhận ngày 21 tháng 3 năm 2017 \\ Chỉnh sửa ngày 05 tháng 4 năm 2017; Chấp nhận đăng ngày 28 tháng 6 năm 2017
}

\begin{abstract}
Tóm tắt: Biến đổi khí hậu và nước biển dâng đang ngày càng làm trầm trọng hơn tình trạng xâm nhập mặn tại các khu vực đồng bằng ven biển. Xâm nhập mặn ảnh hưởng đến cơ sở hạ tầng, kinh tế, xã hội, sinh kế và đời sống dân cư địa phương. Trên cơ sở phương pháp đánh giá tính dễ bị tổn thương của IPCC-UNESCO IHE, nghiên cứu này tập trung làm rõ khả năng dễ bị tổn thương ở cấp độ phường, xã trên địa bàn thành phố Đà Nẵng do nhiễm mặn. Khả năng dễ bị tổn thương được đánh giá thông qua ba thành phần là mức độ phơi bày, mức độ nhạy cảm và năng lực thích ứng, dựa trên 5 hợp phần: kinh tế, xã hội, điều kiện tự nhiên - môi trường - sinh thái, cơ sở hạ tầng và quản trị đô thị. Kết quả nghiên cứu cho thấy khả năng dễ bị tổn thương do nhiễm mặn ở Đà Nẵng cao nhất thuộc về hai xã Hòa Quý và Hòa Xuân; 11 phường, xã được xếp vào nhóm có tính dễ bị tổn thương cao; 21 phường, xã có tính dễ bị tổn thương trung bình; 22 phường, xã được xếp vào nhóm tổn thương thấp.
\end{abstract}

Từ khóa: Xâm nhập mặn, nước biển dâng, đánh giá tổn thương, năng lực thích ứng, Đà Nẵng.

\section{Mở đầu}

Theo kịch bản biến đổi khí hậu $(\mathrm{BĐKH)} \mathrm{và}$ nước biển dâng cho Việt Nam, sự gia tăng nhiệt độ, biến động lượng mưa và nước biển dâng là những mối đe dọa lớn đối với Việt Nam trong những năm tới $[1,2]$. Cùng với mực nước biển dâng, tình trạng hạn hán và hệ quả tiếp theo là xâm nhập mặn đang gia tăng rõ rệt tại những vùng đồng bằng châu thổ và duyên hải Việt Nam. Xâm nhập mặn tác động tiêu cực đến sản

\footnotetext{
*Tác giả liên hệ. ĐT.: 84-904964168

Email: trucnn@vnu.edu.vn

https://doi.org/10.25073/2588-1094/vnuees.4105
}

xuất nông nghiệp, hệ sinh thái, môi trường và cơ sở hạ tầng tại các khu vực chịu ảnh hưởng [3]. Dưới tác động ngày càng lớn của $\mathrm{B} Đ K H$, đặc biệt là xâm nhập mặn, việc nghiên cứu và đánh giá tích hợp khả năng dễ bị tổn thương của hệ thống kinh tế xã hội, cơ sở hạ tầng và môi trường sinh thái có ý nghĩa vô cùng quan trọng.

Trên thế giới đã có những mô hình đánh giá tổn thương được áp dụng từ lâu. Mô hình của NOAA [4] bao gồm các bước: nhận định các tai biến, đánh giá mức độ nguy hiểm do các tai biến, và mật độ các đối tượng bị tổn thương. Mô hình của Cutter [5] đánh giá tổn thương của hệ thống tự nhiên, xã hội. Điểm nổi bật của mô 
hình này là nhận định tổn thương thay đổi theo thời gian, do tai biến gây ra và phụ thuộc và khả năng phục hồi của hệ thống tự nhiên hoặc xã hội. Đến năm 2000, Cutter đã nghiên cứu tổn thương xã hội do tai biến môi trường, trong đó có các yếu tố tổn thương như cơ sở hạ tầng, giao thông, văn hóa [6]... Đối với nhiễm mặn, có thể áp dụng các mô hình này để đánh giá tổn thương ở các khía cạnh thủy văn, môi trường, cơ sở hạ tầng và sản xuất nông nghiệp.

Nhiễm mặn ở vùng duyên hải miền trung mặc dù không ảnh hưởng lớn như ở đồng bằng sông Hồng và sông Cửu Long nhưng cũng gây thiệt hại đáng kể. Đà Nẵng có diện tích tự nhiên $1.256,53 \mathrm{~km}^{2}$, gồm 8 quận, huyện với địa hình dạng đồng bằng và đồi núi. Vùng đồng bằng tập trung ở phía đông và đông nam thành phố, là vùng đất thấp ven biển tập trung nhiều cơ sở nông nghiệp, công nghiệp, dịch vụ và là vùng chịu ảnh hưởng của nhiễm mặn. Xâm nhập mặn ở Đà Nẵng xuất hiện đồng thời với hạn hán. Nếu hạn càng nặng thì mức độ xâm nhập mặn càng cao và thường xảy ra mạnh vào các tháng khô hạn hất. Tình trạng xâm nhập mặn sâu và kéo dài đã ảnh hưởng nghiêm trọng đến sản xuất của trên 700 ha đất nông nghiệp dọc theo lưu vực sông Vĩnh Điện và sông Yên và tác động đến đời sống của khoảng 50.000 người dân các xã Hoà Quý, Hoà Hải, Hoà Xuân, Hoà Tiến, Hoà Khương, Hoà Phong.

\section{Phương pháp nghiên cứu và cơ sở số liệu}

\subsection{Phuong pháp đánh giá tổn thuoong theo} IPCC và UNESCO-IHE

Chỉ số dễ bị tổn thương được tính toán từ các chỉ số thành phần theo mô hình của IPCC [7] và UNESCO-IHE [8], theo công thức: $\mathrm{V}=$ $\mathrm{E}+\mathrm{S}-\mathrm{AC}^{(*)}$, trong đó, $\mathrm{V}$ là mức độ tổn thương, $\mathrm{E}$ là mức độ phơi bày $\mathrm{S}$ là tính nhạy cảm, và $\mathrm{AC}$ là khả năng thích ứng. Công thức được diễn giải theo sơ đồ dưới đây:

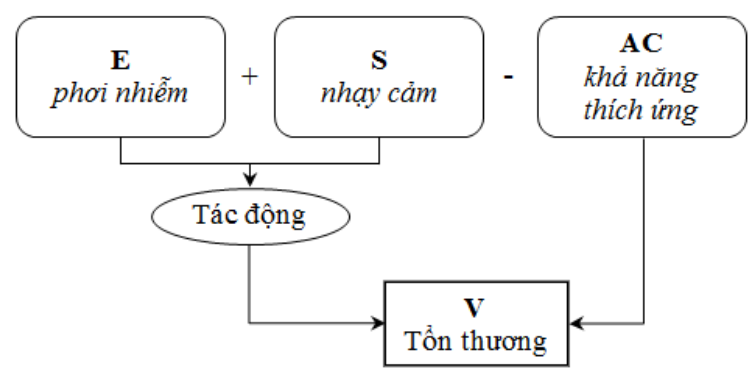

Hình 1. Sơ đồ đánh giá chỉ số dễ bị tổn thương.

Trong nghiên cứu, sẽ lựa chọn một nhóm các chỉ số thích hợp để đánh giá rêng cho từng hợp phần của chỉ số dễ bị tổn thương. Cụ thể, các chỉ số đánh giá mức độ phơi bày trước nhiễm mặn được lựa chọn dựa trên các yếu tố như: nồng độ muối, hạn hán, ngập lụt, nước biển dâng và triều cường. Các chỉ số đánh giá mức độ nhạy cảm và năng lực thích ứng được phân chia theo 5 nhóm: Xã hội, Kinh tế, Tự nhiên - Môi trường - Sinh thái, Cơ sở hạ tầng và Quản trị.

Các chỉ số có đơn vị và tỷ lệ khác nhau nên khi sử dụng trong một hàm quan hệ phải được chuẩn hóa trước khi tính giá trị dễ bị tổn thương. Tùy theo tương quan giữa chỉ số với tính dễ bị tổn thương mà sử dụng hàm quan hệ thuận hoặc quan hệ nghịch để chuẩn hóa. Giá trị chuẩn hóa của các biến sẽ nằm trong khoảng 0 1 , càng tiệm cận 1 nghĩa là mức độ dễ bị tổn thương càng cao.

Công thức thuận: Hàm quan hệ thuận (giá trị chỉ số càng tăng thì mức độ tổn thương càng giảm)

$$
x_{\mathrm{ij}}=\frac{X_{\mathrm{ij}}-\operatorname{Min}_{i}\left\{X_{\mathrm{ij}}\right\}}{\operatorname{Max}_{i}\left\{X_{\mathrm{ij}}\right\}-\operatorname{Min}_{i}\left\{X_{\mathrm{ij}}\right\}}
$$

Công thức nghịch: Hàm quan hệ nghịch (giá trị chỉ số càng giảm thì mức độ tổn thương càng tăng)

$$
y_{\mathrm{ij}}=\frac{\operatorname{Max}_{i}\left\{X_{\mathrm{ij}}\right\}-X_{\mathrm{ij}}}{\operatorname{Max}_{i}\left\{X_{\mathrm{ij}}\right\}-\operatorname{Min}_{i}\left\{X_{\mathrm{ij}}\right\}}
$$

Trong đó: $\mathrm{x}_{\mathrm{ij}}, \mathrm{y}_{\mathrm{ij}}$ là giá trị chuẩn hóa ở tiêu chí $i$ của phường/xã $j$, 
$\mathrm{X}_{\mathrm{ij}}$ là giá trị chưa được chuẩn hóa ở tiêu chí $i$ của phường/xã $j$,

Max và Min là giá trị lớn nhất và nhỏ nhất của vùng theo từng lớp thông tin.

\subsection{Cơ sở số liệu}

Số liệu phỏng vấn điều tra khảo sát xã hội hoc: Nguồn số liệu chính để tính toán khả năng dễ bị tổn thương thu thập qua điều tra khảo sát xã hội học tại Đà Nẵng. Số liệu phỏng vấn cán bộ quản lý các sở ngành bao gồm Sở Nông nghiệp và Phát triển Nông thôn, Ban chỉ huy phòng chống lụt bão, Sở Xây dựng, Văn phòng Ban chỉ đạo Ứng phó biến đổi khí hậu và nước biển dâng thành phố Đà Nẵng, Viện Nghiên cứu Phát triển Kinh tế - Xã hội thành phố Đà Nẵng, cán bộ các phòng chuyên môn thuộc các quận, huyện: Sơn Trà, Cẩm Lệ, Thanh Khê, Hải Châu, Ngũ Hành Sơn, Liên Chiểu, Hòa Vang; số liệu phỏng vấn hộ gia đình trên địa bàn thành phố Đà Nẵng về điều kiện kinh tế, sinh kế gia đình, hiện trạng và tác động của nhiễm mặn. Tổng số phiếu thu thập được là trên 2700.

Số liệu tù khảo sát thực địa, phân tích hiện truòng và thi nghiệm trong phòng: Khảo sát, đo đạc, lấy mẫu và phân tích hiện trường được thực hiện thông qua các đợt thực địa nhằm thu thập thông tin, đánh giá, cập nhật các số liệu thực tế tại địa bàn nghiên cứu về hiện trạng nhiễm mặn, mức độ tác động và thiệt hại xảy ra.

Số liệu thống kê: Từ niên giám thống kê năm 2012 của các quận, huyện và số liệu được cung cấp bởi UBND thành phố Đà Nẵng $[9,10$, 11, 12], Viện Nghiên cứu Phát triển KT-XH Đà Nẵng, Văn phòng Ban chỉ đạo Ứng phó biến đổi khí hậu và nước biển dâng thành phố Đà Nẵng.

\section{Hiện trạng và tác động của nhiễm mặn đối với Đà Nẵng}

\subsection{Hiện trang nhiễm mặn}

Xâm nhập mặn tại Đà Nẵng thường xuất hiện đồng thời với hạn hán. Nếu hạn càng nặng thì mức độ xâm nhập mặn càng cao và thường xuất hiện cao điểm vào các tháng mùa khô. Kết quả khảo sát hiện trạng nhiễm mặn được so sánh với các báo cáo trước đây của Đà Nẵng nhằm đánh giá xu thế và diễn biến. Việc đánh giá hiện trạng được thực hiện thông qua phân tích mẫu nước mặt (là nước sông, hồ) và một phần nước ngầm (nước giếng khoan, đào).

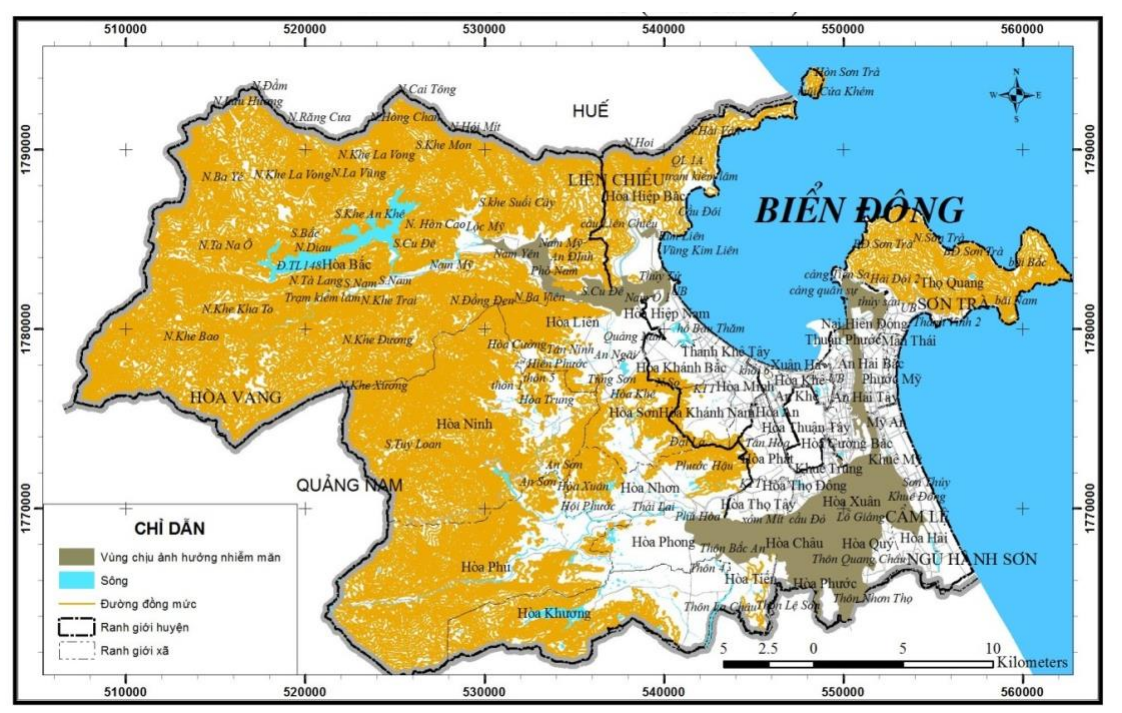

Hình 2. Bản đồ nguy cơ nhiễm mặn thành phố Đà Nẵng (phần đất liền). 
Kết quả khảo sát cho thấy hệ thống sông ngòi khu vực Đà Nẵng hầu hết đã bị nhiễm mặn, cụ thể: đoạn Sông Hàn bị nhiễm mặn toàn bộ; Sông Cổ Cò tình trạng nhiễm mặn giảm do đã xây cống ngăn mặn, nhiễm mặn tại đoạn qua chùa Quan Âm phường Hòa Hải hầu như không đáng kể; Sông Đô Toa bị nhiễm mặn toàn bộ đến hết địa phận Đà Nẵng; đoạn Sông Cẩm Lệ nhiễm mặn toàn bộ; đoạn Sông Cầu Đỏ nhiễm mặn toàn bộ nhưng chỉ khi triều lên; Sông Túy Loan nhiễm mặn đến cầu Túy Loan; Sông Yên bị nhiễm mặn sâu khoảng $3 \mathrm{~km}$ từ ngã ba sông Cầu Đỏ - Túy Loan - sông Yên; Sông $\mathrm{Cu}$ Đê nhiễm mặn gần hết, vào sâu đến giữa xã Hòa Bắc. Các hồ chứa nước kín, không thông với sông thì chưa bị nhiễm mặn. Các kênh rạch thông với biển thì bị nhiễm mặn theo mực nước thủy triều. Trên cơ sở hiện trạng, bài báo đã xây dựng được bản đồ nguy cơ tác động của nhiễm mặn cho khu vực thành phố Đà Nẵng (hình 2).

Tình trạng xâm nhập mặn sâu và kéo dài dọc theo lưu vực các con sông đang ảnh hưởng nghiêm trọng đến trên 700 ha đất sản xuất nông nghiệp ven các con sông này. Xâm nhập mặn làm tăng nguy cơ thiếu nước ngọt cấp cho sản xuất nông nghiệp, công nghiệp và sinh hoạt. Do đó, có nguy cơ ảnh hưởng đến đời sống của khoảng 50.000 người dân các xã Hoà Quý, Hoà Hải, Hoà Xuân, Hoà Tiến, Hoà Khương, Hoà Phong. Hàng năm, vào những tháng mùa khô, hơn 700.000 người dân nội thành thiếu nước sinh hoạt, hàng ngàn cơ sở sản xuất, dịch vụ bị đình trệ sản xuất sẽ là mối đe dọa cho sự phát triển của thành phố.

\subsection{Tác động của nhiếm mặn}

\section{hạ tầng \\ 3.2.1. Tác động của nhiếm mặn đến co sỏ}

Ở khía cạnh cơ sở hạ tầng, nhiễm mặn ảnh hưởng đến nền đất và nền móng công trình, đường giao thông, cầu cống, hệ thống cấp nước, hệ thống thủy lợi... Cụ thể, nhiễm mặn làm biến đổi các thông số địa kỹ thuật đất nền, từ đó thay đổi các đặc điểm cố kêt, biến dạng và sức chịu tải nền đất, tác động đến nền móng và công trình trên đó. Nhiễm mặn phá vỡ kết cấu công trình, bong tróc bề mặt đê kè thủy lợi, ăn mòn bê tông, làm gỉ sét đường ống dẫn nước và lõi thép của các kết cấu bê tông. Nhiễm mặn làm giảm tuổi thọ công trình do muối hòa tan phản ứng với các hợp phần xi măng và cốt thép, các loại khoáng vật sét nhạy cảm trong đất làm chúng mất đi các thuộc tính tốt ban đầu.

Nhiễm mặn trên địa bàn Đà Nẵng còn ảnh hưởng đến hệ thống tưới tiêu phục vụ nông nghiệp và cấp nước sinh hoạt của thành phố. Ranh giới mặn $1,0 \mathrm{~g} / 1$ trên các con sông ngày càng mở rộng về phía thượng nguồn, làm cho các nhà máy nước sạch trước đây vận hành cấp nước bình thường cho thành phố thì nay phải dừng do độ mặn nước mặt đã vượt chỉ tiêu cho phép. Một phần nguyên nhân được xác định do có nhiều công trình thủy điện và thủy lợi tích nước về mùa khô ở đầu nguồn.

\subsubsection{Tác động của nhiễm mặn đến kinh tế} - $x \tilde{a}$ hội

Tình trạng gia tăng xâm nhập mặn đe dọa đến sản xuất nông nghiệp tại nhiều nơi ở Đà Nẵng. Việc chuyển dịch cơ cấu giống cây trồng và lịch thời vụ đã được thực hiện như một giải pháp của ngành nông nghiệp trong ứng phó với nhiễm mặn. Dọc theo sông $\mathrm{Cu}$ Đê thuộc các xã Hòa Liên và Hòa Bắc, để ứng phó với hạn hán và xâm nhập mặn, người dân đã chủ động trồng cây mía, ngô và sắn để thay thế cho diện tích trồng lúa trước đây. Cũng tại đây, một số diện tích đất nhiễm mặn đã được chuyển đổi sang đất nuôi trồng thủy sản. Sinh kế của người dân vùng nhiễm mặn bị ảnh hưởng đáng kể. Cụ thể, ở khu vực nông thôn tại hạ lưu ba con sông Cẩm Lệ, Vĩnh Điện và Cổ Cò thuộc các phường Hòa Xuân, Hòa Quý, Hòa Hải, và dọc lưu vực sông $\mathrm{Cu}$ Đê thuộc địa phận các xã Hòa Bắc, Hòa Liên, tình trạng nhiễm mặn cả nước mặt và nước ngầm khá trầm trọng. Tình trạng thiếu nước ngọt phục vụ sản xuất nông nghiệp và sinh hoạt rất phổ biến. Bên cạnh đó, vì là vùng nhiễm mặn nên chính quyền thành phố đã quy hoạch thành các khu đô thị và đô thị sông nước. Hệ quả là nhân dân nông thôn khu vực này đang bị mất sinh kế, không có đất để sản xuất 
nông nghiệp, nuôi trồng thủy sản ít hiệu quả, trong khi chưa có nghề mới.

Nhiễm mặn còn ảnh hưởng đến sức khỏe của người dân. Khi nhiễm mặn, dẫn đến tình trạng thiếu nước ngọt, người dân phải khoan sâu lấy nước sinh hoạt. Tuy nhiên, nước ngầm bị ô nhiễm khá nặng, một phần bị nhiễm mặn, một phần bị nhiê̂̀m phèn, sắt và hữu cơ, điển hình như tại phường Hòa Xuân, Hòa Quý. Đó là nguyên nhân có thể dẫn đến các loại bệnh về tiêu hóa, và hô hấp cho nhân dân sinh sống tại khu vực này.

\section{Khả năng dễ bị tổn thương do nhiễm mặn trong bối cảnh biến đổi khí hậu ở Đà Nẵng}

\subsection{Chỉ số phơi bày với nhiễm mặn (E)}

Chỉ số phơi bày (exposure, E) là để chỉ mức độ tác động của thiên tai, khí hậu và do biến đổi khí hậu gây ra. Các chỉ số phơi bày với nhiễm mặn trong nghiên cứu gồm: nồng độ muối trong nước mặt và nước ngầm, diện tích vùng úng ngập thường xuyên, diện tích vùng hạn hán thường xuyên, khả năng mực nước biển dâng và triều cường cực đại (bảng 1 ). Đây là bốn yếu tố chính thể hiện mức độ phơi bày với nhiễm mặn khu vực Đà Nẵng trong mối quan hệ với biến đổi khí hậu, đặc biệt là yếu tố nước biển dâng và triều cường cực đại. Chúng đều có tương quan tỉ lệ thuận với tính dễ bị tổn thương.

Từ các dữ liệu đầu vào là thông tin định tính và giá trị định lượng của các yếu tố phơi nhiễm với tai biến nhiễm mặn, việc tính toán đã thu được giá trị chỉ số phơi nhiễm của mỗi hợp phần. Chỉ số phơi bày với tai biến nhiễm mặn tại Đà Nã̃ng là giá trị trung bình các yếu tố thể hiện sự phơi bày trước nhiễm mặn. Chúng được chuẩn hóa, quy đổi về tỉ lệ $0-1$ và được đánh giá theo bốn mức độ: thấp, trung bình, cao và rất cao (bảng 2)

Bảng 1. Chỉ số phơi bày và mối tương quan với tổn thương

\begin{tabular}{ll}
\hline Phơi bày $(\mathrm{E})$ & $\begin{array}{l}\text { Tương quan với } \\
\text { tổn thương }\end{array}$ \\
\hline Nồng độ muối & Tỉ lệ thuận \\
Nước biển dâng \& triều cường & Tỉ lệ thuận \\
Hạn hán & Tỉ lệ thuận \\
Diện tích úng ngập & Tỉ lệ thuận \\
\hline
\end{tabular}

Bảng 2. Bảng giá trị chỉ số mức độ phơi nhiễm đới với tai biến nhiễm mặn thành phố Đà Nẵng

\begin{tabular}{lllll}
\hline TT & Tên phường, xã & $\begin{array}{l}\text { E tính toán } \\
\text { trung bình }\end{array}$ & $\begin{array}{l}\text { E quy đổi } \\
\text { về tỉ lệ } 0-1\end{array}$ & $\begin{array}{l}\text { Mức độ phơi } \\
\text { bày }\end{array}$ \\
\hline 1 & Hòa Ninh & 0 & 0 & Thấp \\
2 & Hòa Khánh Nam & 0 & 0 & Thấp \\
3 & Hòa Minh & 0 & 0 & Thấp \\
4 & Thạc Gián & 0,001 & 0,001 & Thấp \\
5 & Thanh Khê Đông & 0,001 & 0,002 & Thấp \\
6 & Xuân Hà & 0,002 & 0,003 & Thấp \\
7 & Hòa Phú & 0,004 & 0,006 & Thấp \\
8 & Chính Gián & 0,005 & 0,008 & Thấp \\
9 & Hòa Bắc & 0,01 & 0,016 & Thấp \\
10 & Hòa Sơn & 0,014 & 0,023 & Thấp \\
11 & Thọ Quang & 0,017 & 0,028 & Thấp \\
12 & Hòa Thuận Tây & 0,019 & 0,031 & Thấp \\
13 & Hòa Khánh Bắc & 0,022 & 0,035 & Thấp \\
14 & Thanh Khê Tây & 0,022 & 0,035 & Thấp \\
15 & Hòa Khương & 0,025 & 0,04 & Thấp \\
\hline
\end{tabular}




\begin{tabular}{lllll}
\hline 16 & Hòa Nhơn & 0,025 & 0,04 & Thấp \\
17 & Phước Mỹ & 0,027 & 0,044 & Thấp \\
18 & Vĩnh Trung & 0,029 & 0,047 & Thấp \\
19 & Tam Thuận & 0,057 & 0,092 & Thấp \\
20 & Mân Thái & 0,072 & 0,116 & Thấp \\
21 & Hòa Phát & 0,074 & 0,12 & Thấp \\
22 & Hòa Phong & 0,081 & 0,13 & Thấp \\
23 & An Khê & 0,086 & 0,139 & Thấp \\
24 & Hòa An & 0,099 & 0,16 & Thấp \\
25 & Nam Dương & 0,115 & 0,186 & Thấp \\
26 & Hải Châu 2 & 0,127 & 0,206 & Trung bình \\
27 & Tân Chính & 0,129 & 0,208 & Trung bình \\
28 & Hòa Hải & 0,133 & 0,215 & Trung bình \\
29 & Hòa Thọ Tây & 0,138 & 0,224 & Trung bình \\
30 & Hòa Khê & 0,149 & 0,241 & Trung bình \\
31 & An Hải Bắc & 0,184 & 0,297 & Trung bình \\
32 & An Hải Đông & 0,199 & 0,323 & Trung bình \\
33 & Thanh Bình & 0,21 & 0,34 & Trung bình \\
34 & Hòa Tiến & 0,212 & 0,344 & Trung bình \\
35 & Khuê Mỹ & 0,221 & 0,358 & Trung bình \\
36 & Hòa Phước & 0,267 & 0,432 & Cao \\
37 & Hòa Liên & 0,278 & 0,451 & Cao \\
38 & Hòa Cường Nam & 0,279 & 0,453 & Cao \\
39 & Khuê Trung & 0,287 & 0,464 & Cao \\
40 & Hòa Hiệp Nam & 0,293 & 0,475 & Cao \\
41 & Hòa Thọ Đông & 0,305 & 0,494 & Cao \\
42 & Bình Thuận & 0,311 & 0,503 & Cao \\
43 & Hòa Hiệp Bắc & 0,33 & 0,535 & Cao \\
44 & Hòa Cường Bắc & 0,334 & 0,541 & Cao \\
45 & Mỹ An & 0,337 & 0,547 & Cao \\
46 & Hòa Thuận Đông & 0,383 & 0,62 & Cao \\
47 & Hải Châu 1 & 0,393 & 0,637 & Cao \\
48 & Thạch Thắng & 0,423 & 0,685 & Cao \\
49 & Phước Ninh & 0,443 & 0,718 & Cao \\
50 & Bình Hiên & 0,444 & 0,719 & Cao \\
51 & An Hải Tây & 0,473 & 0,766 & Cao \\
52 & Thuận Phước & 0,488 & 0,79 & Rất cao \\
53 & Hòa Châu & 0,506 & 0,819 & Rát cao \\
54 & Nại Hiên Đông & 0,56 & 0,907 & Rát cao \\
55 & Hòa Quý & 0,614 & 0,996 & Rất cao \\
56 & Hòa Xuân & 0,617 & 1,0 & Rât cao \\
\hline & & & &
\end{tabular}


Từ giá trị chỉ số mức độ phơi bày của các hợp phần đối với nhiễm mặn, đặc biệt là giá trị phân chia các ngưỡng mức độ phơi bày, bản đồ mức độ phơi bày tai biến nhiễm mặn thành phố Đà Nẵng đã được thành lập (hình 3 ). Theo nguyên tắc về cấu trúc đơn vị hành chính, bản đồ phơi bày với nhiễm mặn được xây dựng theo cấp phường. Có 4 cấp độ phân chia mức độ phơi bày là thấp, trung bình, cao và rất cao, tương ứng với các giá trị trên bảng 2 . Kết quả hiển thị trên bản đồ cho thấy, các khu vực bị ảnh hưởng của nhiễm mặn nhiều nhất là nơi thể hiện mức độ phơi nhiễm lớn nhất, chủ yếu thuộc hạ lưu sông Hàn và sông $\mathrm{Cu}$ Đê. Đặc biệt, các phường nằm kẹp giữa ba con sông Cẩm Lệ, Vĩnh Điện và Cổ Cò.

\subsection{Chỉ số nhạy cảm với nhiếm mặn $(S)$}

Chỉ số nhạy cảm với nhiễm mặn (sensitivity, $S$ ) được đánh giá theo 5 hợp phần: xã hội, kinh tế, điều kiện tự nhiên - môi trường - sinh thái, cơ sở hạ tầng và quản trị đô thị; tương ứng với 15 chỉ số khác nhau được sử dụng trong tính toán. Năm hợp phần với 15 chỉ số này về cơ bản đã bao hàm gần hết các lĩnh vực quan trọng tại Đà Nẵng, nhất là các lĩnh vực liên quan trực tiếp hoặc một phần gián tiếp với nhiễm mặn. Trên bảng 3 là các giá trị chỉ số nhạy cảm với tai biến nhiễm mặn của thành phố Đà Nẵng.

Giá trị trung bình của các chỉ số được quy đổi về tỉ lệ từ $0-1$ và phân chia thành 4 cấp đánh giá tương tự như mức độ phơi bày. Theo đó, kết quả tính toán chỉ số nhạy cảm với nhiễm mặn của Đà Nẵng theo cấp phường, xã như sau: có 11 phường/xã được xếp vào nhóm có chỉ số nhạy cảm rất cao; 9 phường xã được xếp vào nhóm nhạy cảm cao, 19 phường nhóm trung bình và 17 phường thuộc nhóm thấp (bảng 4). Bản đồ mức độ nhạy cảm với tai biến nhiễm mặn được thể hiện trên hình 3. Do được phân chia và đánh giá theo cấp phường/xã nên một phường/xã dù chỉ bị nhiễm mặn một phần nhỏ nhưng nghiêm trọng thì vẫn bị xếp vào nhóm nhạy cảm rất cao, ví dụ xã Hòa Bắc, Hòa Ninh, Hòa Phú.

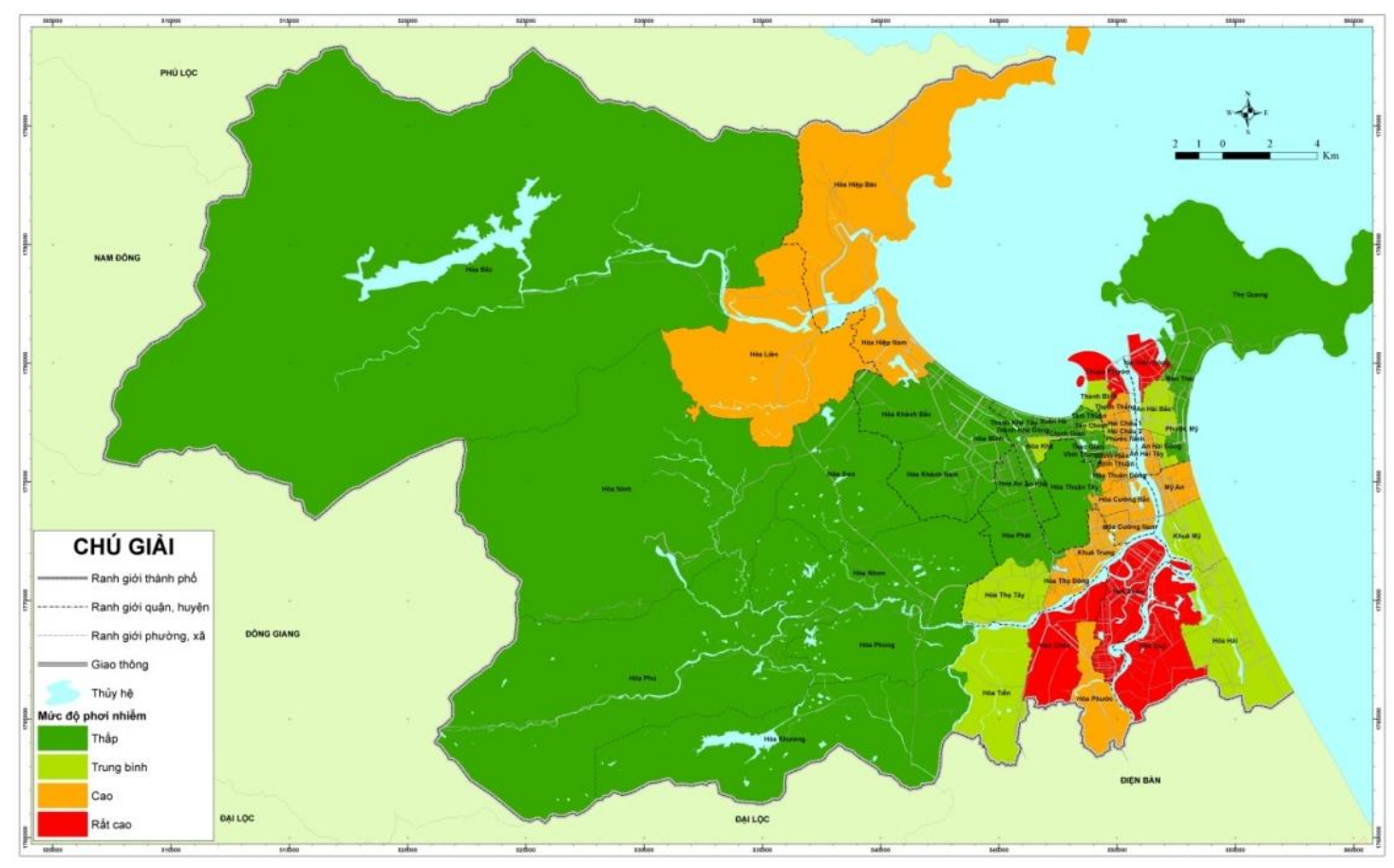

Hình 3. Bản đồ mức độ phơi bày với tai biến nhiễm mặn thành phố Đà Nẵng (phần đất liền). 
Bảng 3. Chỉ số mức độ nhạy cảm với nhiễm mặn và mối tương quan với tính dễ bị tổn thương

\begin{tabular}{|c|c|c|}
\hline Hợp phần & Chỉ số & $\begin{array}{l}\text { Tương quan với tổn } \\
\text { thương }\end{array}$ \\
\hline \multirow{4}{*}{$X \tilde{a} h \hat{o} i$} & Tỷ lệ hộ nghèo & Thuận \\
\hline & Tỉ lệ người dân làm nông nghiệp & Thuận \\
\hline & Mức độ đáp ứng nhu cầu cấp nước (mức độ hài lòng) & Nghịch \\
\hline & Tỉ lệ số người chưa đến/quá tuổi lao động. & Thuận \\
\hline Kinh tế & Mức độ tác động của thiên tai đến sinh kế & Thuận \\
\hline \multirow{3}{*}{$\begin{array}{l}\text { Tư nhiên - } \\
\text { Môi truoòng - } \\
\text { Sinh thái }\end{array}$} & Loại hình sử dụng đất nông nghiệp & Thuận \\
\hline & Độ cao địa hình & Nghịch \\
\hline & Chỉ số nhạy cảm của hệ thống thủy vực & Thuận \\
\hline \multirow{5}{*}{ Cơ sở hạ tầng } & Hệ thống cấp nước sinh hoạt & Thuận \\
\hline & Hệ thống thoát nước & Nghịch \\
\hline & Nguồn nước chính của gia đình sử dụng hàng ngày & Thuận \\
\hline & Nguồn nước chính của gia đình khi có tai biến & Thuận \\
\hline & Hệ thống đường giao thông & Thuận \\
\hline \multirow{2}{*}{ Quản trị } & Tham gia đóng góp ý kiến XD và quy hoạch đô thị & Nghịch \\
\hline & Mức độ ổn định an ninh trật tự đô thị & Nghịch \\
\hline
\end{tabular}

Bảng 4. Giá trị chỉ số mức độ nhạy cảm với tai biến nhiễm mặn thành phố Đà Nẵng

\begin{tabular}{lllll}
\hline TT & Tên phường & \multicolumn{2}{l}{ S trung bình tính S quy đối về } & Mức độ nhạy cảm \\
\hline 1 & Khuê Mỹ & 0,182 & 0 & Thấp \\
2 & Hải Châu 2 & 0,183 & 0,006 & Thấp \\
3 & Xuân Hà & 0,193 & 0,041 & Thấp \\
4 & An Hải Đông & 0,197 & 0,056 & Thấp \\
5 & Hòa Hiệp Nam & 0,197 & 0,057 & Thấp \\
6 & Phước Mỹ & 0,202 & 0,074 & Thấp \\
7 & Hòa Khánh Bắc & 0,203 & 0,08 & Thấp \\
8 & Mân Thái & 0,208 & 0,096 & Thấp \\
9 & Hòa Thuận Tây & 0,213 & 0,116 & Thấp \\
10 & Vĩnh Trung & 0,225 & 0,163 & Thấp \\
11 & Bình Hiên & 0,232 & 0,188 & Thấp \\
12 & Hòa An & 0,237 & 0,204 & Thấp \\
13 & Thanh Khê Tây & 0,239 & 0,214 & Thấp \\
14 & Hòa Cường Bắc & 0,242 & 0,226 & Thấp \\
15 & Hòa Phát & 0,244 & 0,233 & Thấp \\
16 & Thanh Khê Đông & 0,248 & 0,246 & Thấp \\
17 & Tam Thuận & 0,248 & 0,246 & Thấp \\
18 & Hòa Khánh Nam & 0,249 & 0,253 & Trung bình \\
19 & Hòa Khê & 0,255 & 0,273 & Trung bình \\
20 & Chính Gián & 0,257 & 0,28 & Trung bình \\
\hline & & &
\end{tabular}




\begin{tabular}{|c|c|c|c|c|}
\hline 21 & Thọ Quang & 0,262 & 0,299 & Trung bình \\
\hline 22 & An Hải Bắc & 0,265 & 0,313 & Trung bình \\
\hline 23 & Nam Dương & 0,267 & 0,32 & Trung bình \\
\hline 24 & Thuận Phước & 0,273 & 0,343 & Trung bình \\
\hline 25 & Thanh Bình & 0,275 & 0,347 & Trung bình \\
\hline 26 & Hòa Phong & 0,28 & 0,368 & Trung bình \\
\hline 27 & Hòa Khương & 0,283 & 0,379 & Trung bình \\
\hline 28 & Tân Chính & 0,285 & 0,387 & Trung bình \\
\hline 29 & Thạc Gián & 0,291 & 0,408 & Trung bình \\
\hline 30 & Bình Thuận & 0,299 & 0,439 & Trung bình \\
\hline 31 & An Khê & 0,301 & 0,447 & Trung bình \\
\hline 32 & Hòa Thọ Tây & 0,303 & 0,454 & Trung bình \\
\hline 33 & Hòa Thuận Đông & 0,305 & 0,463 & Trung bình \\
\hline 34 & Hòa Châu & 0,306 & 0,463 & Trung bình \\
\hline 35 & Hòa Thọ Đông & 0,307 & 0,469 & Trung bình \\
\hline 36 & Thạch Thắng & 0,311 & 0,482 & Trung bình \\
\hline 37 & Hòa Tiến & 0,315 & 0,501 & Cao \\
\hline 38 & Khuê Trung & 0,326 & 0,541 & Cao \\
\hline 39 & Phước Ninh & 0,338 & 0,585 & Cao \\
\hline 40 & Hòa Minh & 0,339 & 0,59 & Cao \\
\hline 41 & Hòa Hiệp Bắc & 0,345 & 0,613 & Cao \\
\hline 42 & Hòa Cường Nam & 0,35 & 0,63 & Cao \\
\hline 43 & Hòa Hải & 0,351 & 0,634 & $\mathrm{Cao}$ \\
\hline 44 & Hòa Sơn & 0,353 & 0,643 & $\mathrm{Cao}$ \\
\hline 45 & Hải Châu 1 & 0,368 & 0,698 & Cao \\
\hline 46 & An Hải Tây & 0,388 & 0,772 & Rất cao \\
\hline 47 & Hòa Phước & 0,39 & 0,781 & Rất cao \\
\hline 48 & Hòa Nhơn & 0,394 & 0,795 & Rất cao \\
\hline 49 & Mỹ An & 0,396 & 0,802 & Rất cao \\
\hline 50 & Hòa Liên & 0,397 & 0,808 & Rất cao \\
\hline 51 & Nại Hiên Đông & 0,397 & 0,808 & Rất cao \\
\hline 52 & Hòa Phú & 0,412 & 0,864 & Rất cao \\
\hline 53 & Hòa Ninh & 0,413 & 0,865 & Rất cao \\
\hline 54 & Hòa Bắc & 0,43 & 0,93 & Rất cao \\
\hline 55 & Hòa Quý & 0,438 & 0,958 & Rất cao \\
\hline 56 & Hòa Xuân & 0,449 & 1 & Rất cao \\
\hline
\end{tabular}




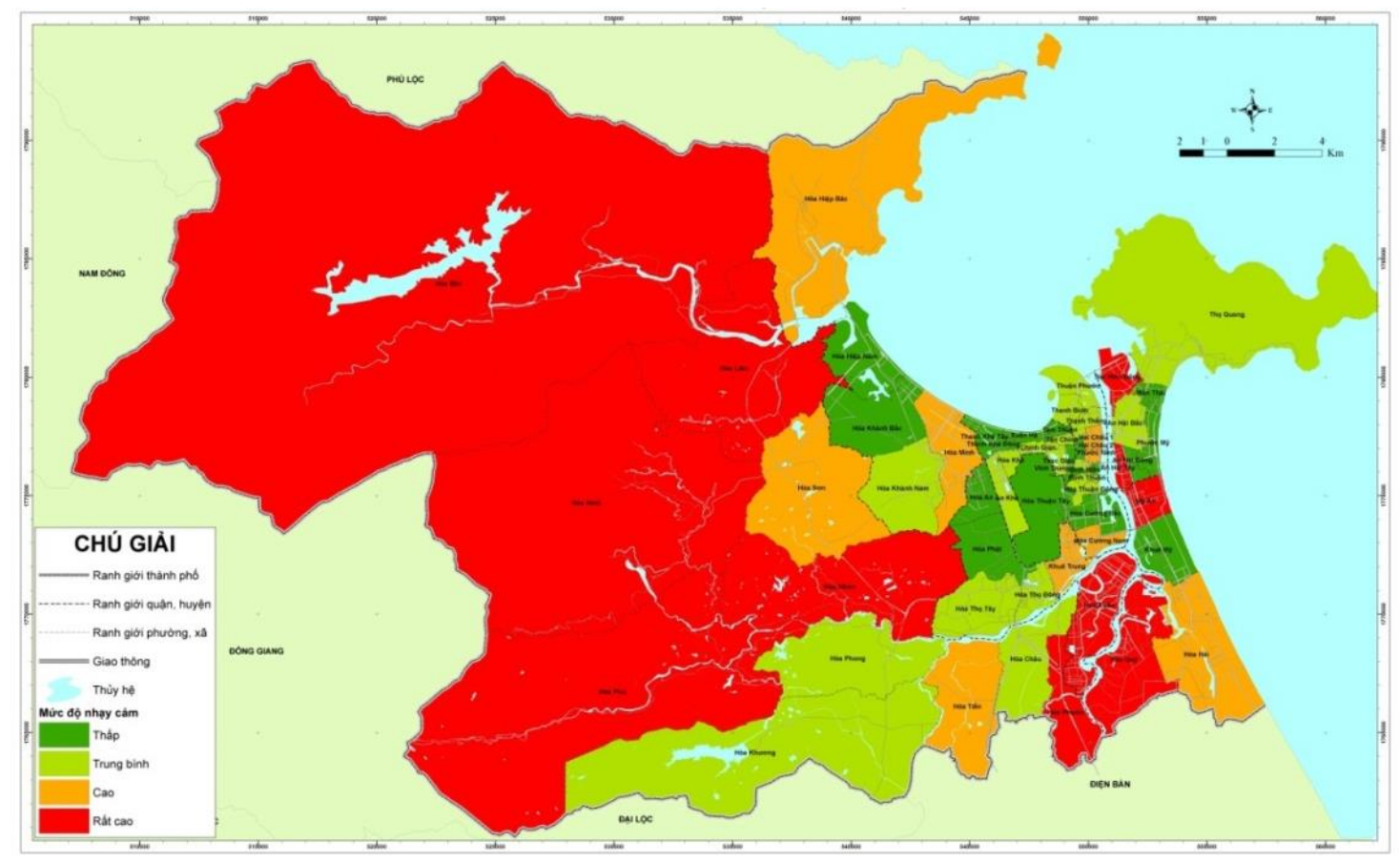

Hình 4. Bản đồ mức độ nhạy cảm với tai biến nhiễm mặn thành phố Đà Nẵng (phần đất liền).

\subsection{Chỉ số năng lực thich ưng (AC)}

Tính toán chỉ số năng lực thích ứng (adaptive capacity, AC) được thực hiện theo quy trình 4 bước (hình 5) cho năm hợp phần: điều kiện tự nhiên- môi trường- sinh thái, kinh tế, xã hội, cơ sở hạ tầng đô thị, quản trị đô thị. Chỉ số năng lực thích ứng với nhiễm mặn có được bằng cách xử lí số liệu của phiếu điều tra và khảo sát hộ dân sinh sống trên địa bàn liên quan đến nhiễm mặn, kết hợp với niên giám thống kê của TP. Đà Nẵng. Các bước thực hiện như sau:

Bước 1: Xử lý phiếu được tiến hành từ 2473 phiếu điều tra hộ dân, lọc ra được 465 phiếu liên quan đến nhiễm mặn trên toàn thành phố,

Bước 2: Tổng hợp lại các số liệu dựa vào các tiêu chí để đánh giá năng lực thích ứng,

Bước 3: Sử dụng công thức thuận ở trên để tính chỉ số theo từng tiêu chí,

Bước 4: Tính trung bình cộng của các chỉ số ở cùng một hợp phần.
Cuối cùng có được kết quả đánh giá năng lực thích ứng với nhiễm mặn của Đà Nẫng.

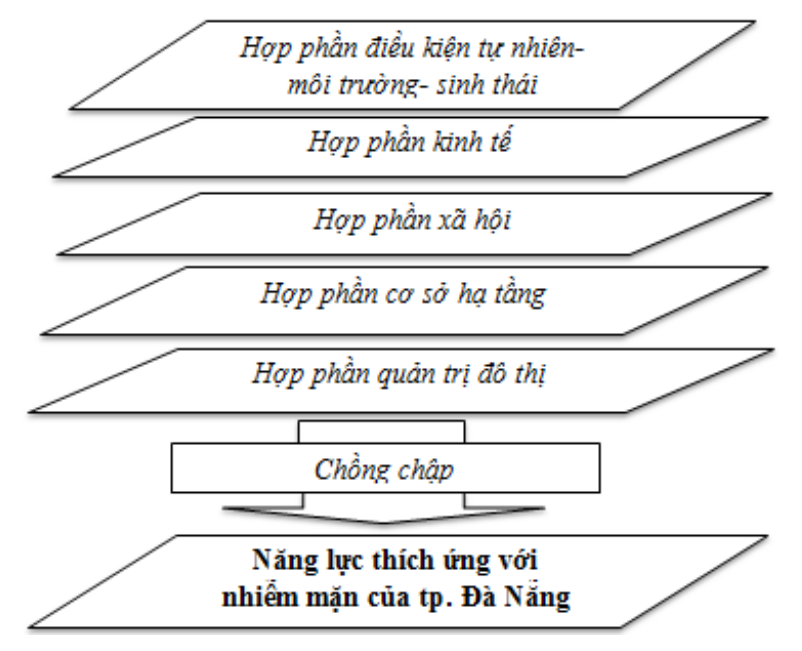

Hình 5. Sơ đồ đánh giá năng lực thích ứng với nhiễm mặn

Chỉ số năng lực thích ứng với nhiễm mặn của thành phố Đà Nẵng được đánh giá dựa trên năm hợp phần, với 25 chỉ số được trình bày trên bảng 5 . 
Bảng 5. Chỉ số năng lực thích ứng và mức độ ảnh hưởng tới khả năng thích ứng với nhiễm mặn

\begin{tabular}{|c|c|c|}
\hline Hợp phần & Chỉ số & $\begin{array}{l}\text { Mức độ ảnh hưởng tăng (+), giảm (-) } \\
\text { khả năng thích ứng }\end{array}$ \\
\hline \multirow{5}{*}{$\begin{array}{l}\text { Tự nhiên - môi } \\
\text { trường - sinh } \\
\text { thái }\end{array}$} & Ô nhiễm nước & $\begin{array}{l}\text { Không ô nhiễm (+) } \\
\text { Ô nhiễ̂m (-) }\end{array}$ \\
\hline & $\begin{array}{l}\text { Số lượng, chất lượng các nguồn nước sử dụng } \\
\text { trong thời gian xảy ra tai biến }\end{array}$ & $\begin{array}{l}\text { Nước máy (+) } \\
\text { Nước giếng, nước mưa (-) }\end{array}$ \\
\hline & Mức độ hài lòng về nguồn cấp nước & $\begin{array}{l}\text { Hài lòng (+) } \\
\text { Bình thường, không hài lòng(-) }\end{array}$ \\
\hline & Ô nhiễm đất & $\begin{array}{l}\text { Không ô nhiễm (+) } \\
\text { Ô nhiê̂̀m (-) }\end{array}$ \\
\hline & Ô nhiễm không khí & $\begin{array}{l}\text { Không ô nhiễm (+) } \\
\text { Ô nhiễ̂m (-) }\end{array}$ \\
\hline \multirow{4}{*}{ Kinh tế } & Thu nhập hộ gia đình & $\begin{array}{l}\text { Thu nhập, mức sống cao }(+), \\
\text { Thu nhập, mức sống trung bình, } \\
\text { Thu nhập, mức sống thấp (-) }\end{array}$ \\
\hline & Đa dạng sinh kế & $\begin{array}{l}\text { Ít loại sinh kế (-), } \\
\text { Nhiều sinh kế (+) }\end{array}$ \\
\hline & Tỷ lệ người có việc làm & $\begin{array}{l}\text { Có việc làm (+) } \\
\text { Không có việc làm (-) }\end{array}$ \\
\hline & Tỷ lệ người tham gia các loại bảo hiểm & $\begin{array}{l}\text { Tham gia (+) } \\
\text { Không tham gia (-) }\end{array}$ \\
\hline \multirow{11}{*}{$X \tilde{a} h \hat{o} i$} & $\begin{array}{l}\text { Chuẩn bị các dụng cụ phòng chống thiên tai, thích } \\
\text { ứng BĐKH }\end{array}$ & $\begin{array}{l}\text { Có vật dụng }(+) \\
\text { Không có vật dụng (-) }\end{array}$ \\
\hline & $\begin{array}{l}\text { Tham gia các lớp tập huấn, tuyên truyền, chương } \\
\text { trình diễn tập phòng chống thiên tai, thích ứng } \\
\text { BĐKH }\end{array}$ & $\begin{array}{l}\text { Tham gia tập huấn (+), } \\
\text { Không tham gia tập huấn (-) }\end{array}$ \\
\hline & $\begin{array}{l}\text { Chia sẻ, trao đổi thông tin kinh nghiệm về thiên } \\
\text { tai, BĐKH }\end{array}$ & $\begin{array}{l}\text { Thường xuyên chia sẻ thông tin }(+) \\
\text { Không thường xuyên chia sẻ thông tin } \\
(-)\end{array}$ \\
\hline & Theo dõi tivi, đài, báo & $\begin{array}{l}\text { Có theo dõi (+) } \\
\text { Không theo dõi (-) }\end{array}$ \\
\hline & Tham gia quỹ cộng đồng & $\begin{array}{l}\text { Không tham gia (-) } \\
\text { Tham gia (+) }\end{array}$ \\
\hline & Trình độ học vấn & $\begin{array}{l}\text { Trình độ học vấn cao (+) } \\
\text { Trình độ học vấn thấp (-) }\end{array}$ \\
\hline & $\begin{array}{l}\text { Vai trò của sinh kế đối với khả năng thích ứng } \\
\text { BĐKH }\end{array}$ & $\begin{array}{l}\text { Rất quan trọng, quan trọng vừa }(+) \\
\text { Không quan trọng }(-)\end{array}$ \\
\hline & $\begin{array}{l}\text { Cảm nhận của người dân khi nghe thông tin bất } \\
\text { thường về thiên tai }\end{array}$ & $\begin{array}{l}\text { Bình thường }(+) \\
\text { Rất lo lắng, lo lắng }(-)\end{array}$ \\
\hline & Tự đánh giá khả năng thích ứng với $\mathrm{BĐKH}$ & $\begin{array}{l}\text { Tốt, trung bình }(+) \\
\text { Kém }(-)\end{array}$ \\
\hline & Tỷ lệ người trong và ngoài độ tuổi lao động & $\begin{array}{l}\text { Trong độ tuổi lao động(+) } \\
\text { Ngoài độ tuôii lao động(-) }\end{array}$ \\
\hline & Tỷ lệ nam/ nữ & $\begin{array}{l}\text { Nam }(+) \\
\text { Nữ }(-)\end{array}$ \\
\hline
\end{tabular}




\begin{tabular}{|c|c|c|}
\hline \multirow{3}{*}{ Co' sở hạ tầng } & Chất lượng các cơ sở y tế & $\begin{array}{l}\text { Hiệu quả (+) } \\
\text { Bình thường (-) }\end{array}$ \\
\hline & Khả năng thu gom xử lý rác thải tại địa phương & $\begin{array}{l}\text { Có điểm thu gom rác thải }(+) \\
\text { Không có điềm thu gom rác }(-)\end{array}$ \\
\hline & Chất lượng nguồn điện & $\begin{array}{l}\text { Hiểm khi mất điện }(+) \\
\text { Thường xuyên mất điện }(-)\end{array}$ \\
\hline \multirow[t]{2}{*}{ Quản trị đô thị } & $\begin{array}{l}\text { Tham gia, đóng góp ý kiến của người dân trong } \\
\text { xây dựng quy hoạch đô thị }\end{array}$ & $\begin{array}{l}\text { Có tham gia }(+) \\
\text { Không và chưa tham gia }(-)\end{array}$ \\
\hline & Mức độ ổn định an ninh trật tự đô thị & $\begin{array}{l}\text { Rất ổn định (+) } \\
\text { Mất ổn định (-) }\end{array}$ \\
\hline
\end{tabular}

Giá trị tính toán chỉ số năng lực thích ứng trung bình của thành phố dao động trong khoảng từ 0,405 đến 0,781 . Chỉ số này được quy đổi tương ứng tỉ lệ 0-1 sau đó được phân chia theo 4 cấp: vùng có khả năng thích ứng thấp, trung bình, cao và rất cao (bảng 6).

Bảng 6. Phân vùng năng lực thích ứng theo cấp phường của thành phố Đà Nẵng

\begin{tabular}{|c|c|c|c|c|}
\hline $\mathrm{TT}$ & Tên phường & $\begin{array}{l}\text { AC trung bình } \\
\text { tính toán }\end{array}$ & $\begin{array}{l}\text { AC quy đổi về } \\
\text { tỉ lệ } 0-1\end{array}$ & $\begin{array}{l}\text { Khả năng thích } \\
\text { ứng }\end{array}$ \\
\hline 1 & Khuê Trung & 0.405 & 0.000 & Thấp \\
\hline 2 & Hòa Xuân & 0.500 & 0.251 & Thấp \\
\hline 3 & Hòa Hiệp Bắc & 0.549 & 0.383 & Trung bình \\
\hline 4 & Hòa Sơn & 0.557 & 0.404 & Trung bình \\
\hline 5 & Hòa Nhơn & 0.568 & 0.434 & Trung bình \\
\hline 6 & Hòa Quý & 0.587 & 0.484 & Trung bình \\
\hline 7 & Hòa Liên & 0.588 & 0.488 & Trung bình \\
\hline 8 & Hòa Phú & 0.597 & 0.511 & Trung bình \\
\hline 9 & An Khê & 0.603 & 0.526 & $\mathrm{Cao}$ \\
\hline 10 & Hòa Phát & 0.604 & 0.528 & Cao \\
\hline 11 & Nại Hiên Đông & 0.609 & 0.542 & $\mathrm{Cao}$ \\
\hline 12 & Hòa Ninh & 0.613 & 0.553 & Cao \\
\hline 13 & Hòa Phong & 0.614 & 0.557 & $\mathrm{Cao}$ \\
\hline 14 & Hòa Bắc & 0.631 & 0.602 & Cao \\
\hline 15 & Hòa Hải & 0.632 & 0.604 & Cao \\
\hline 16 & Hòa Châu & 0.636 & 0.613 & Cao \\
\hline 17 & Hòa Thuận Đông & 0.638 & 0.619 & $\mathrm{CaO}$ \\
\hline 18 & Hòa Thọ Đông & 0.649 & 0.649 & Cao \\
\hline 19 & Hòa Khánh Bắc & 0.650 & 0.653 & $\mathrm{Cao}$ \\
\hline 20 & Mỹ An & 0.653 & 0.661 & Cao \\
\hline 21 & Chính Gián & 0.663 & 0.686 & Cao \\
\hline 22 & Thanh Khê Đông & 0.663 & 0.686 & $\mathrm{CaO}$ \\
\hline 23 & Thanh Khê Tây & 0.672 & 0.711 & Cao \\
\hline 24 & Hòa An & 0.673 & 0.713 & Cao \\
\hline
\end{tabular}




\begin{tabular}{|c|c|c|c|c|}
\hline 25 & Hải Châu 1 & 0.675 & 0.718 & Cao \\
\hline 26 & Hòa Khánh Nam & 0.676 & 0.721 & Cao \\
\hline 27 & Thọ Quang & 0.674 & 0.716 & Cao \\
\hline 28 & Thạc Gián & 0.677 & 0.723 & Cao \\
\hline 29 & Hòa Cường Nam & 0.680 & 0.733 & $\mathrm{Cao}$ \\
\hline 30 & Hòa Phước & 0.682 & 0.736 & Cao \\
\hline 31 & Tân Chính & 0.682 & 0.736 & Cao \\
\hline 32 & Hòa Thuận Tây & 0.690 & 0.760 & Rất cao \\
\hline 33 & Tam Thuận & 0.692 & 0.763 & Rất cao \\
\hline 34 & Hòa Khương & 0.695 & 0.773 & Rất cao \\
\hline 35 & Mân Thái & 0.696 & 0.774 & Rất cao \\
\hline 36 & An Hải Tây & 0.699 & 0.783 & Rất cao \\
\hline 37 & Bình Thuận & 0.699 & 0.783 & Rất cao \\
\hline 38 & Hòa Thọ Tây & 0.703 & 0.792 & Rất cao \\
\hline 39 & Thạch Thắng & 0.707 & 0.803 & Rất cao \\
\hline 40 & Khuê Mỹ & 0.708 & 0.806 & Rất cao \\
\hline 41 & An Hải Bắc & 0.709 & 0.808 & Rất cao \\
\hline 42 & Phước Mỹ & 0.712 & 0.818 & Rất cao \\
\hline 43 & Thanh Bình & 0.713 & 0.821 & Rất cao \\
\hline 44 & Hòa Tiến & 0.715 & 0.825 & Rất cao \\
\hline 45 & Xuân Hà & 0.724 & 0.850 & Rất cao \\
\hline 46 & Vĩnh Trung & 0.726 & 0.855 & Rất cao \\
\hline 47 & Hải Châu 2 & 0.727 & 0.858 & Rất cao \\
\hline 48 & Thuận Phước & 0.729 & 0.863 & Rất cao \\
\hline 49 & Hòa Khê & 0.730 & 0.866 & Rất cao \\
\hline 50 & Hòa Minh & 0.735 & 0.878 & Rất cao \\
\hline 51 & An Hải Đông & 0.744 & 0.903 & Rất cao \\
\hline 52 & Bình Hiên & 0.749 & 0.916 & Rất cao \\
\hline 53 & Phước Ninh & 0.750 & 0.918 & Rất cao \\
\hline 54 & Hòa Hiệp Nam & 0.751 & 0.920 & Rất cao \\
\hline 55 & Nam Dương & 0.752 & 0.925 & Rất cao \\
\hline 56 & Hòa Cường Bắc & 0.781 & 1.000 & Rất cao \\
\hline
\end{tabular}

Kết quả tính toán định lượng trên bảng 5 cho thấy, phường Khuê Trung và Hòa Xuân thuộc quận Cẩm Lệ có khả năng thích ứng với nhiễm mặn thấp nhất, với chỉ số năng lực thích ứng lần lượt là 0,405 và 0,500 . Các quận Hải Châu, Sơn Trà và Thanh Khê có chỉ số thích ứng thuộc vùng cao và rất cao, đặc biệt là quận Hải Châu với 13 phường thì có đến 10 phường được đánh giá là có khả năng thích ứng rất cao và 3 phường còn lại được đánh giá là khả năng thích ứng cao. Các quận/huyện còn lại là huyện Hòa Vang, quận Liên Chiểu và Ngũ Hành Sơn còn xen lẫn các xã/phường có khả năng thích ứng trung bình với xã/phường có khả năng thích ứng cao và rất cao. Nhưng nhìn chung chỉ số thích ứng của các xã/phường này cũng ở mức tương đối cao. 


\subsection{Chỉ số dễ bị tổn thương (V)}

Từ các giá trị mức độ phơi bày $(\mathrm{E})$, độ nhạy cảm $(\mathrm{S})$ và năng lực thích ứng $(\mathrm{AC})$ có thể tính toán được chỉ số về tính dễ bị tổn thương với nhiễm mặn quy mô phường, xã theo công thức (*). Các giá trị tính toán chỉ số khả năng dễ bị tổn thương theo năm hợp phần: điều kiện tự nhiên - môi trường- sinh thái, kinh tế, xã hội, cơ sở hạ tầng đô thị, quản trị đô thị, vớicác thành phần mức độ nhạy cảm, năng lực thích ứng và phơi nhiễm được cho trên bảng 6 . Giá trị chỉ số tổn thương do nhiễm mặn thành phố Đà Nẵng giao động khá lớn, từ -0.8 đến 1.7 . Giá trị này được quy đổi theo tỉ lệ $0-1$, sau đó được đánh giá theo 4 cấp: tổn thương thấp (Vquy đổi= $0 \div 0.25$ ), tổn thương trung bình (Vquy đổi $=$ $0.25 \div 0.5)$, tổn thương cao $\left(\mathrm{V}_{\text {quy đồi }}=0.5 \div 0.75\right)$ và tổn thương rất cao $\left(\mathrm{V}_{\text {quy đổi }}=0.75 \div 1\right)$.

Kết quả đánh giá khả năng dễ bị tổn thương với nhiễm mặn theo đơn vị hành chính cấp phường cho thành phố Đà Nẵng được thể hiện trên bản đồ dưới đây (hình 7). Vùng tổn thương cao có màu đỏ, là vùng có mức độ nhạy cảm cao, phơi bày cao và năng lực thích ứng thấp. Ngược lại, phần màu xanh lục thể hiện khả năng dễ bị tổn thương thấp, chủ yếu là nơi có địa hình cao, hoặc vùng đô thị, ít nhạy cảm và năng lực thích ứng cao.

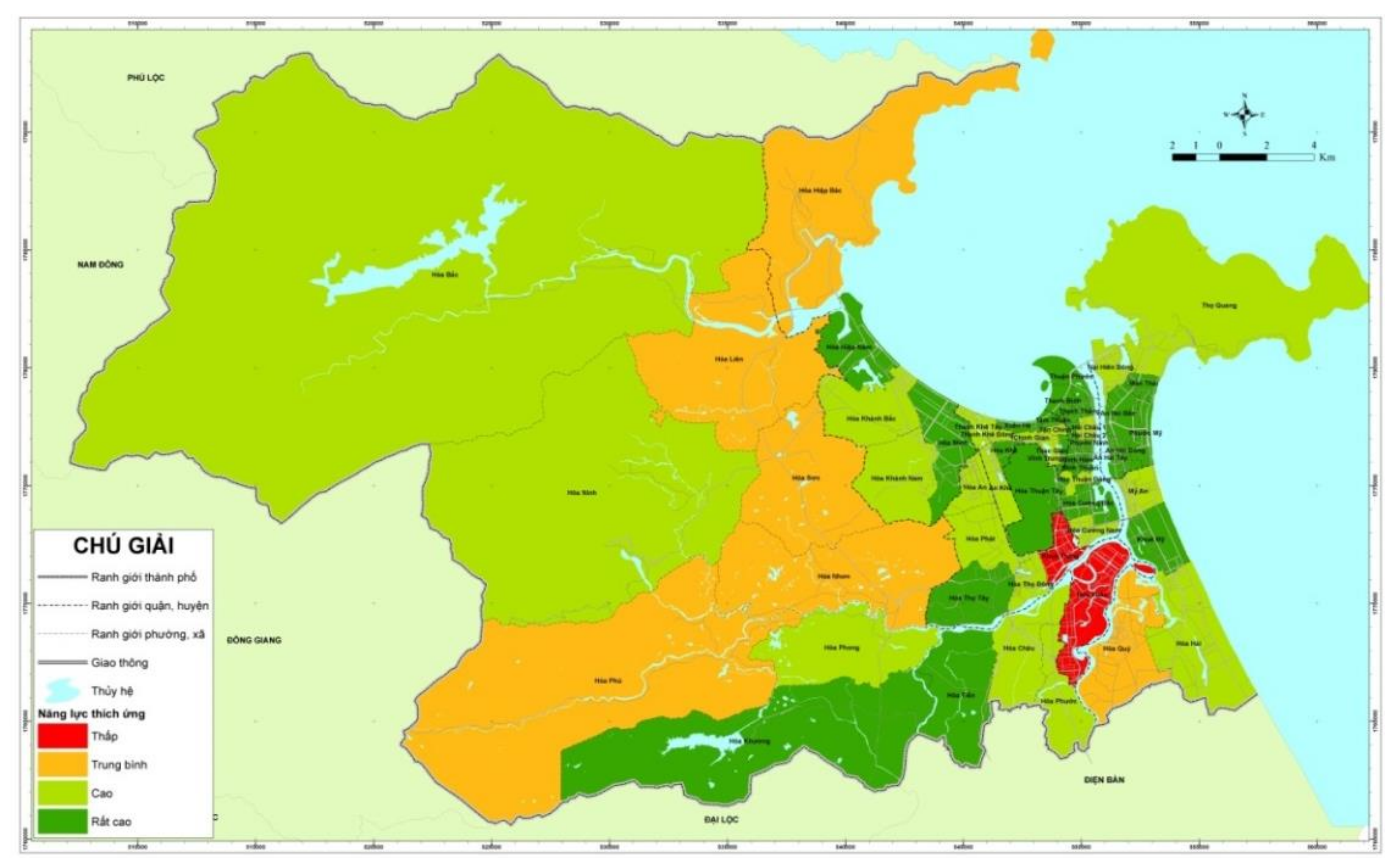

Hình 6. Bản đồ năng lực thích ứng với nhiễm mặn của thành phố Đà Nẵng (phần đất liền).

Bảng 6. Chỉ số dễ bị tổn thương với tai biến nhiễm mặn của Đà Nẵng

\begin{tabular}{lllllll}
\hline & \multicolumn{1}{l}{ Chỉ số } & & & \\
\cline { 2 - 6 } Phường, xã & Phơi bày $(\mathrm{E})$ & Nhạy cảm (S) & $\begin{array}{l}\text { Năng lực thích } \\
\text { ứng }(\mathrm{AC})\end{array}$ & $\begin{array}{l}\text { Giá trị tổn } \\
\text { thương tính } \\
\text { toán }(\mathrm{V})\end{array}$ & $\begin{array}{l}\text { Giá trị tổn } \\
\text { thương quy } \\
\text { đổi }\end{array}$ & $\begin{array}{l}\text { Kị tổn } \\
\text { thương }\end{array}$ \\
\hline Xuân Hà & 0.003 & 0.041 & 0.850 & -0.806 & 0.0 & Thấp \\
Phước Mỹ & 0.044 & 0.074 & 0.818 & -0.700 & 0.041 & Thấp \\
Hải Châu 2 & 0.206 & 0.006 & 0.858 & -0.646 & 0.063 & Thấp \\
\hline
\end{tabular}




\begin{tabular}{|c|c|c|c|c|c|c|}
\hline Vĩnh Trung & 0.047 & 0.163 & 0.855 & -0.645 & 0.063 & Thấp \\
\hline Hòa Thuận Tây & 0.031 & 0.116 & 0.760 & -0.613 & 0.076 & Thấp \\
\hline Mân Thái & 0.116 & 0.097 & 0.774 & -0.561 & 0.096 & Thấp \\
\hline Hòa Khánh Bắc & 0.035 & 0.08 & 0.653 & -0.538 & 0.105 & Thấp \\
\hline An Hải Đông & 0.323 & 0.056 & 0.903 & -0.524 & 0.11 & Thấp \\
\hline Hòa Khánh Nam & 0.0 & 0.253 & 0.721 & -0.468 & 0.132 & Thấp \\
\hline Thanh Khê Tây & 0.035 & 0.214 & 0.711 & -0.462 & 0.135 & Thấp \\
\hline Khuê Mỹ & 0.358 & 0.0 & 0.806 & -0.448 & 0.14 & Thấp \\
\hline Thanh Khê Đông & 0.001 & 0.246 & 0.686 & -0.439 & 0.144 & Thấp \\
\hline Tam Thuận & 0.092 & 0.246 & 0.763 & -0.425 & 0.149 & Thấp \\
\hline Nam Dương & 0.186 & 0.32 & 0.925 & -0.419 & 0.151 & Thấp \\
\hline Chính Gián & 0.008 & 0.28 & 0.686 & -0.398 & 0.16 & Thấp \\
\hline Thọ Quang & 0.028 & 0.299 & 0.716 & -0.389 & 0.163 & Thấp \\
\hline Hòa Hiệp Nam & 0.475 & 0.057 & 0.920 & -0.388 & 0.164 & Thấp \\
\hline Hòa Khương & 0.04 & 0.379 & 0.773 & -0.354 & 0.177 & Thấp \\
\hline Hòa Khê & 0.241 & 0.273 & 0.866 & -0.352 & 0.178 & Thấp \\
\hline Thạc Gián & 0.001 & 0.408 & 0.723 & -0.314 & 0.193 & Thấp \\
\hline Hòa Minh & 0.0 & 0.59 & 0.878 & -0.288 & 0.203 & Thấp \\
\hline Hòa An & 0.16 & 0.205 & 0.620 & -0.255 & 0.216 & Thấp \\
\hline Hòa Cường Bắc & 0.541 & 0.226 & 1.000 & -0.233 & 0.250 & Trung bình \\
\hline An Hải Bắc & 0.297 & 0.313 & 0.808 & -0.198 & 0.252 & Trung bình \\
\hline Hòa Phát & 0.12 & 0.233 & 0.528 & -0.175 & 0.255 & Trung bình \\
\hline Tân Chính & 0.208 & 0.387 & 0.736 & -0.141 & 0.26 & Trung bình \\
\hline Thanh Bình & 0.34 & 0.347 & 0.821 & -0.134 & 0.263 & Trung bình \\
\hline Hòa Thọ Tây & 0.224 & 0.454 & 0.792 & -0.114 & 0.271 & Trung bình \\
\hline Hòa Phong & 0.131 & 0.368 & 0.557 & -0.058 & 0.293 & Trung bình \\
\hline Bình Hiên & 0.719 & 0.188 & 0.916 & -0.009 & 0.312 & Trung bình \\
\hline Hòa Tiến & 0.344 & 0.501 & 0.825 & 0.020 & 0.323 & Trung bình \\
\hline An Khê & 0.139 & 0.447 & 0.526 & 0.060 & 0.339 & Trung bình \\
\hline Bình Thuận & 0.503 & 0.439 & 0.783 & 0.159 & 0.378 & Trung bình \\
\hline Hòa Hải & 0.215 & 0.634 & 0.604 & 0.245 & 0.411 & Trung bình \\
\hline Hòa Sơn & 0.023 & 0.643 & 0.404 & 0.262 & 0.418 & Trung bình \\
\hline Thuận Phước & 0.79 & 0.342 & 0.863 & 0.269 & 0.421 & Trung bình \\
\hline Hòa Ninh & 0 & 0.865 & 0.553 & 0.312 & 0.438 & Trung bình \\
\hline Hòa Thọ Đông & 0.494 & 0.468 & 0.649 & 0.313 & 0.438 & Trung bình \\
\hline Hòa Bắc & 0.016 & 0.93 & 0.602 & 0.344 & 0.45 & Trung bình \\
\hline Hòa Cường Nam & 0.453 & 0.63 & 0.733 & 0.350 & 0.452 & Trung bình \\
\hline Hòa Phú & 0.006 & 0.864 & 0.511 & 0.359 & 0.456 & Trung bình \\
\hline
\end{tabular}




\begin{tabular}{lllllll}
\hline Phước Ninh & 0.718 & 0.585 & 0.918 & 0.385 & 0.466 & Trung bình \\
Hòa Nhơn & 0.04 & 0.795 & 0.434 & 0.401 & 0.472 & Trung bình \\
Thạch Thắng & 0.685 & 0.482 & 0.753 & 0.414 & 0.500 & Cao \\
Hòa Thuận Đông & 0.62 & 0.463 & 0.619 & 0.464 & 0.501 & Cao \\
Hòa Phước & 0.433 & 0.781 & 0.736 & 0.478 & 0.503 & Cao \\
Hải Châu 1 & 0.637 & 0.697 & 0.718 & 0.616 & 0.557 & Cao \\
Hòa Châu & 0.82 & 0.463 & 0.613 & 0.670 & 0.578 & Cao \\
Mỹ An & 0.547 & 0.802 & 0.661 & 0.688 & 0.585 & Cao \\
An Hải Tây & 0.766 & 0.772 & 0.783 & 0.755 & 0.611 & Cao \\
Hòa Hiệp Bắc & 0.534 & 0.613 & 0.383 & 0.764 & 0.614 & Cao \\
Hòa Liên & 0.451 & 0.808 & 0.488 & 0.771 & 0.617 & Cao \\
Khuê Trung & 0.464 & 0.541 & 0.000 & 1.005 & 0.709 & Cao \\
Nại Hiên Đông & 0.907 & 0.808 & 0.542 & 1.173 & 0.774 & Cao \\
Hòa Quý & 0.995 & 0.958 & 0.484 & 1.469 & 0.89 & Rất cao \\
Hòa Xuân & 1.0 & 1.0 & 0.251 & 1.749 & 1.0 & Rất cao \\
\hline
\end{tabular}

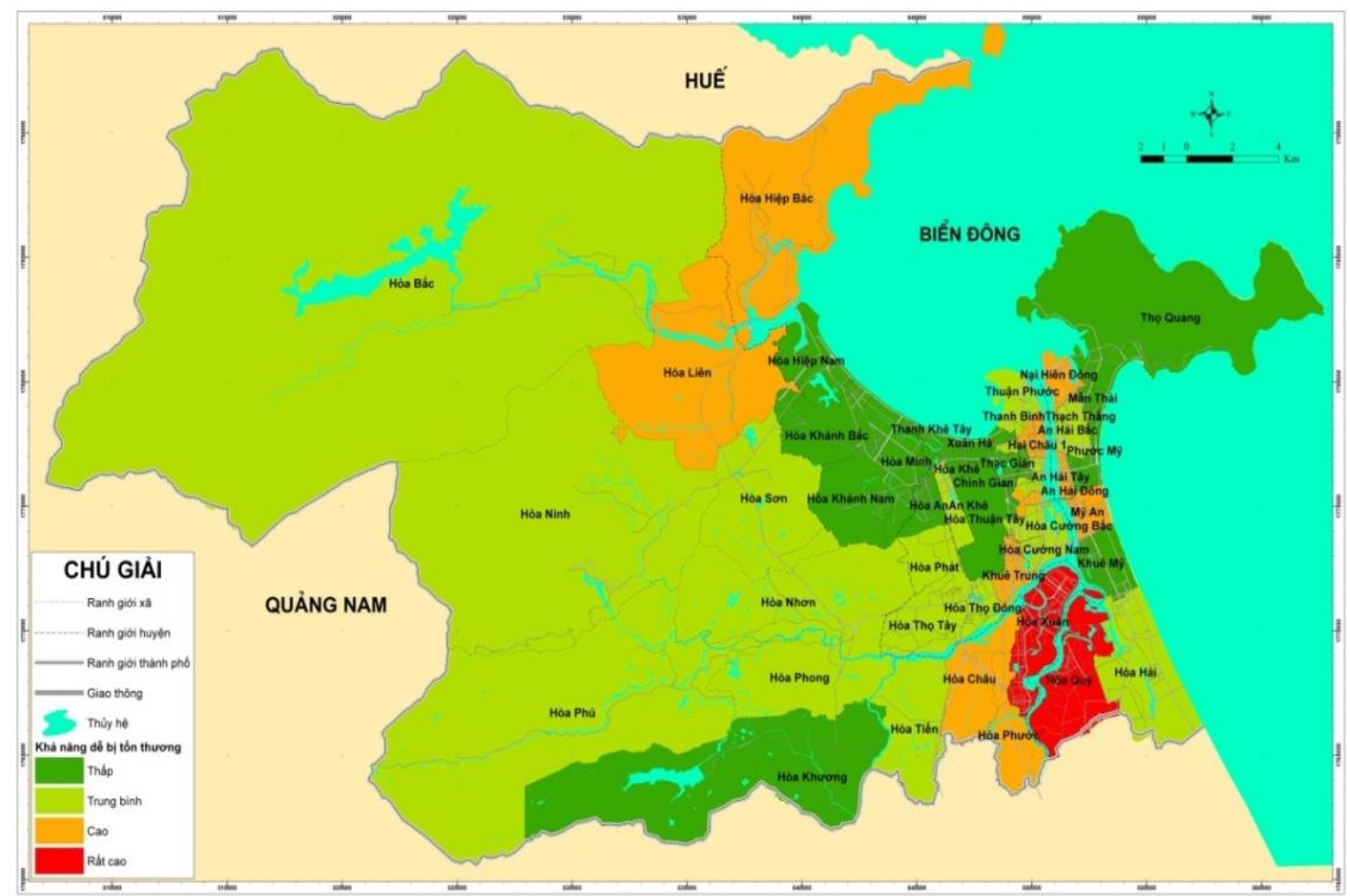

Hình 7. Bản đồ tính dễ bị tổn thương với tai biến nhiễm mặn thành phố Đà Nẵng. 


\subsection{Thảo luận}

Từ kết quả tính toán, đánh giá và bản đồ khả năng dễ bị tổn thương với tai biến nhiễm mặn, có thể nhận thấy ở Đà Nẵng chỉ có 02 phường có khả năng dễ bị tổn thương rất cao; 11 phường, xã có khả năng dễ bị tổn thương cao; 21 phường, xã được xếp vào nhóm trung bình và các phường xã còn lại thuộc nhóm tổn thương thấp. Cụ thể, vùng có tính dễ bị tổn thương rất cao thuộc về phường Hòa Qúy và Hòa Xuân. Đây là hai khu vực trũng thấp nhất thành phố Đà Nẵng, thường xuyên bị ngập lụt, nằm kẹp giữa ba con sông Cẩm lệ- Vĩnh Điện/Đô Toa - Cổ Cò. Đây cũng là vùng được xem như "hạn hán" nhiều nhất do mặc dù bị bao quanh bởi sông nước nhưng lại là nước nhiễm mặn, nhiễm phèn không có khả năng sử dụng cho sinh hoạt và sản xuất nông nghiệp. Vùng có tính dễ bị tổn thương cao gồm 11 phường, xã trong lưu vực các con sông chính của Đà Nẵng là Thạch Thắng, Hòa Thuận Đông, Hòa Phước, Hải Châu 1, Hòa Châu, Mỹ An, An Hải Tây, Hòa Hiệp Bắc, Hòa Liên, Khuê Trung và Nại Hiên Đông. Đây là nhóm phường xã phân bố ở hạ lưu sông $\mathrm{Cu}$ Đê, sông Hàn - Cẩm Lệ và lân cận vùng trũng thấp của ba sông Cẩm lệ- Vĩnh Điện/Đô Toa - Cổ Cò. Vùng có tính dễ bị tổn thương trung bình gồm 21 phường, xã khu vực chưa hoặc ít chịu ảnh hưởng bởi nhiễm mặn, đó là Hòa Cường Bắc, An Hải Bắc, Hòa Phát, Tân Chính, Thanh Bình, Hòa Thọ Tây, Hòa Phong, Bình Hiên, Hòa Tiến, An Khê, Bình Thuận, Hòa Hải, Hòa Sơn, Thuận Phước, Hòa Ninh, Hòa Thọ Đông, Hòa Bắc, Hòa Cường Nam, Hòa Phú, Phước Ninh và Hòa Nhơn. Vùng có tính dễ bị tổn thương thấp chủ yếu thuộc về các xã phường vùng lõi đô thị hoặc xã phường mà sinh kế người dân ít bị ảnh hưởng bởi nhiễm mặn (như du lịch, dịch vụ, thủ công nghiệp...), đó là 22 xã, phường còn lại.

Việc đánh giá tổn thương do nhiễm mặn cho khu vực Đà Nẵng theo năm hợp phần đã được thực hiện theo phương pháp của IPCCUNESCO IHE. Đây là phương pháp mới, có tính định lượng cao, cho kết quả đáng tin cậy.
Để thực hiện được việc đánh giá tổn thương đạt kết quả cao, cần phải tính toán các thành phần mức độ phơi bày, độ nhạy cảm, và năng lực thích ứng. Chúng đòi hỏi bộ số liệu đầu vào rất đầy đủ, chi tiết, đặc biệt phải xác định được các chỉ tiêu phù hợp với mỗi hợp phần và lượng hóa các chỉ tiêu đó. Nghiên cứu này đánh giá tính dễ bị tổn thương cho Đà Nẵng theo quy mô ranh giới hành chính cấp phường, xã. Do đó, một phường, xã bị nhiễm mặn cho dù chỉ ở một khu vực nhỏ thì cũng xem như phường, xã đó bị nhiễm mặn. Khu vực nội thành, nơi có địa hình cao, hoặc khu vực có sinh kế ít bị tác động bởi nhiễm mặn thường có năng lực thích ứng cao và ít bị tổn thương hơn những khu vực khác.

\section{Kết luận}

Chỉ số dễ bị tổn thương đối với tai biến nhiễm mặn của thành phố Đà Nẵng được tính toán từ các chỉ số thành phần như phơi bày $\mathrm{E}$, nhạy cảm $\mathrm{S}$ và năng lực thích ứng $\mathrm{AC}$ theo mô hình của IPCC và UNESCO-IHE. Kết quả tính toán phân tích trên cơ sở số liệu thu thập từ niên giám thống kê thành phố, đặc biệt dựa vào bộ phiếu điều tra phỏng vấn hộ dân toàn thành phố, đã chỉ ra rằng, tai biến nhiễm mặn ở Đà Nẵng đóng vai trò không quá lớn. Khả năng dễ bị tổn thương cao nhất thuộc về hai xã Hòa Quý và Hòa Xuân. Đây là các xã vùng trũng thấp và đang bị tai biến nhiễm mặn đe dọa đến hoạt động kinh tế xã hội và sinh kế người dân. Kết quả nghiên cứu cũng chỉ ra rằng, ở Đà Nẵng có 11 phường xã được xếp vào nhóm có tính dễ bị tổn thương cao, 21 phường xã có tính dễ bị tổn thương trung bình, 22 phường xã được xếp vào nhóm có tính dễ bị tổn thương thấp.

\section{Lời cảm ơn}

Tác giả bài báo xin gửi lời cảm ơn đến sự hỗ trợ của đề tài KHCN cấp Nhà nước "Nghiên cứu và xây dụng mô hình đô thị ven biển có khả năng thích ứng với biến đổi khí hậu" mã số $\mathrm{BĐKH}-32$ ), và sự tư vấn của GS. Mai Trọng Nhuận. 


\section{Tài liệu tham khảo}

[1] Bộ Tài nguyên và Môi trường, 2012. Kịch bản biến đổi khí hậu và nước biển dâng cho Việt Nam. Nhà xuất bản Tài nguyên - Môi trường và Bản đồ Việt Nam.

[2] Bộ Tài nguyên và Môi trường, 2016. Kịch bản biến đổi khí hậu và nước biển dâng cho Việt Nam. Nhà xuất bản Tài nguyên - Môi trường và Bản đồ Việt Nam.

[3] Nguyễn Văn Thắng và nnk, 2010. Biến đổi khí hậu và tác động ở Việt Nam. Nhà Xuất bản Khoa họcvà Kỹ thuật, Trang 196-200.

[4] National Oceanic and Atmospheric Administration (NOAA), 1999. Community vulnerability assessment tool: New Hanover county, North Carolina case study, Washington D.C.
[5] Cutter S. L., 1996. Vulnerability to environmental hazards", Progress in Human Geography 20, p.529.

[6] Cutter S. L., Mitchell J. T., Scott M. S., 2000. Revealing the vulnerability of people and places: a case study of Georgetown county, South Carolina. Annals of the Association of American Geographers, 90 (4),p.713.

[7] IPCC, 2007. IPCC fourth assessment report. The AR4 synthesis report, Glossary.

[8] www.unesco-ihe-fvi.org

[9] Tổng cục Thống kê, 2012. Niên giám thống kê quận Liên Chiểu năm 2012, NXB Thống kê.

[10] Tổng cục Thống kê, 2012. Niên giám thống kê quận Cẩm Lệ năm 2012. Nhà Xuất bản Thống kê.

[11] Tổng cục Thống kê, 2012. Niên giám thống kê huyện Hòa Vang năm 2011 và 2012. Nhà Xuất bản Thống kê.

\title{
Current Status and Vulnerability Induced by Saline Intrusion in The Climate Change Context in Da Nang City
}

\author{
Nguyen Ngoc Truc ${ }^{1}$, Truong Van Thinh ${ }^{2}$, \\ Nguyen Van Thuong ${ }^{1}$, Nguyen Thao Ly ${ }^{1}$ \\ ${ }^{1}$ VNU University of Sciences, 334 Nguyen Trai, Hanoi, Vietnam \\ ${ }^{2}$ Center for VNU Development at Hoa Lac Campus
}

\begin{abstract}
Climate change and sea level rise are exacerbating saline intrusion in the coastal plains. Saline intrusion affects the infrastructure, the economy, society, and local livelihoods. Based on the method of the IPCC-UNESCO IHE, this study focused on the vulnerability assessment induced by saline intrusion at the level of wards and communes in Da Nang. It was carried out through three components, i.e. exposure, sensitivity, and adaptive capacity, with five factors, i.e. economy, society, natural conditions - environment - ecology, infrastructure, and urban governance. The obtained results showed that the highest vulnerability to saline intrusion in Da Nang city is in Hoa Quy and Hoa Xuan communes; 11 wards and communes were classified as highly vulnerable; 21 communes and communes have average vulnerability; 22 wards and communes are classified as low vulnerability.
\end{abstract}

Keywords: Saline intrusion, sea level rise, vulnerability assessment, adaptive capacity, Da Nang. 